\title{
The Analysis of the Science Textbooks for the First Three Grades in the Brimary Education in Jordan in the Domain of Science Process Skills (2017)
}

\author{
Mohammad Nayef Mohammad Alayasrah ${ }^{1} \&$ Shima' Mkhymr Salih Yahyaa ${ }^{1}$ \\ ${ }^{1}$ Department of Educational Sciences, Irbid University College, AlBalqa Applied University, Salt, Jordan \\ Correspondence: Mohammad Nayef Mohammad Alayasrah, Department of Educational Sciences, Irbid \\ University College, AlBalqa Applied University, Salt, Jordan. E-mail: ali200087@yahoo.com
}

Received: September 16, 2017

Accepted: September 26, 2017 Online Published: November 8, 2017

doi:10.5539/res.v9n4p68

URL: http://doi.org/10.5539/res.v9n4p68

\begin{abstract}
The current study aims at detecting the essential and integrated science process skills in the first three grades of the primary education in Jordan using the analytical and descriptive Method. The study population consists of the science textbooks of the first three grades in the primary education in Jordan in 2015/2016.

The sample of the study is its population. The study has shown that the most basic science process skills included in the science textbooks is the observation process. The textbooks also include all the integrated science process skills, and the experimental process is the most frequent one. However, the books do not include the processes of using time and place elations and the connection process. According to its results, the study has recommended the following. The process of using numbers in the science textbooks of the first grade, and also the processes of using time and place processes, and connections process in the first three grades science books along with the basic science process skills in an organized and balanced form, in the first three grades should be included, it also suggests conducting a study about the evaluation of the first three grades teachers, and the changes in the science textbooks of the first three grades in Jordan.
\end{abstract}

Keywords: content analysis, the primary knowledge processes, the integral knowledge processes, science textbooks of the primary education

\section{Introduction}

The curriculum is considered as the tangible interpretation of the purposes existing in the teaching process and forms a clear picture of its level. The curriculum seeks to contribute in the preparation of the individuals who are capable of dealing with innovations, issues and challenges through an integrated system of knowledge, processes and values in a way that ensures the welfare for them and their so cities (Mar'i \& Al-Heclah, 2004).

The school textbook is considered as the base from which the subjects studied by students are derived. It is considered as the reference for teachers when planning their daily lessons, as most teachers make it as the basis for determining what to teach and why they will do it (Bennett, 2003; Seaem, 2013). The textbook is an essential part for the success of what the curriculum has been set for. Countries change of modify their curricula in order to meet their societies' needs and the world in which they live (Khataybeh, 2011).

People of education believe that the basic scientific knowledge learnt by students in the first grades help them to discover the basic thoughts which help them to understand the components of science and its processes as the modern view of scientific education emphasizes that one of the most important aims of teaching sciences in the primary grades is the enabling of students to acquire necessary science processes for scientific thinking by students conducting scientific investigations requiring basically their practicing of the scientific processes which enable them to understand the best sciences (Zaytoon, 2009; Badawi, 2003).

American Association for the Advancement of Science (AAAS), 1973, determined two sections for science processes, the first relating to the Basic science processes skills, namely, observation, measurement, classification, prediction using numbers, using place and time relationships, and communication; and the other integrated science process skills, namely, suggesting hypotheses, data interpretation, procedural identifications, control of variables and experimentation (Martin, Sexton, \& Gerlouich, 2001; Gega, 1994; Caring \& Sand, 1975). 
The science processes, with their both already mentioned sections, form a hieratical building which moves the learnet between its layers when mastered. Where the first primary stage is specific for teaching students the basic science processes in a concentrated way in order to enable them to perform the integrated science processes which require a high thinking level (Tobin \& Capie, 1982).

For achieving that, the curriculum guidelines should emphasize students' performance of science processes represented in mental and practical activities and practices which all form the perception of sciences through science textbooks in the first grades, students, through them, student's form their knowledge and acquired the necessary experience for the problems which face them and develop their intellectual and social capabilities (Ministry of Education, 2014). They are procedural processes which form the student's mind habits.

That is why they should be dealt with and taught in the first school grades because they go with students in the coming educational stages (Al-Qadiri, 2004).

Bronze pointed out the necessity for science processes to be the purpose of learning in childhood stage and as the basic stage is considered as one of the most important stages by all categories of society and its institutions as they affect students attitudes towards science and achievement tests (Department of Education, UK, 2009). This requires the continuity of analysis to determine their appropriateness for students' maturity, their levels and their linguistic and mental capabilities (Banikhelef, 2001). As a result of the cognitive and practical importance of science processes in teaching sciences and their direct impact on the students understanding of scientific concepts (Abu Aathirahn, 2012; Chine, Brown, \& Bruce, 2002). They should be effectively included in the basic stage science textbooks as they are on important criterion whose influence cannot be neglected on the success of the school textbook in the accomplishment of a successful scientific curriculum, not just a curriculum which talks about sciences (Zaytoon, 2010).

\section{Literature}

An investigator of the theoretical frame, with all researches and studies included about science processes, notices that they have been dealt with from different perspectives, at the top of which is the students' mastering degree and their abilities to practice them (Al-Seifi, 2011; Al-Suaydi, 2010), the influence of some instructional strategies on students' acquisition and the relationship between students' acquisition of science processes and their academic achievement (Al-Qatrawi, 2010; Al-Ba'li \& Al-Harahshih, 2012; Simesek \& Kahapinar, 2010). Other studies, like this, were interested in the analysis of science textbooks to find out the extent of their inclusion of science processes (Abdulhadi, 2003; Al-quteish, 2012; Abu Jahjoun, 2008; Abdulmajeed, 2004; Al-Shu'aili \& Khatagybah, 2003; Al-Dawsari \& Omar, 2013; Dokme, 2005; Aziz \& Zain, 2010). The grades whose content was analyzed for this purpose varied. The two researchers will emphasize the studies which investigated the extent of the inclusion of science processes in the science textbooks similar to the study in the study stage dealt with.

Anderson (1992) conducted a study based on the analysis of scientific activities in science textbooks for the elementary and preparatory stages in order to judge their level through their inclusion of science processes and the activities in these textbooks were classified among the good category.

Morrow (1994) analyzed the science textbook for the first three grades with the aim of identifying their ability to develop students' environmental culture. It appeared through the results that the capability of the analyzed textbooks to develop the skills of science processes was little.

Al-Aagha and Al-Za'aneen (2000) conducted a study with the aim of determining the availability extent of the elements of scientific prediction in six science textbooks for the elementary stage in Palestine. The process of content analysis revealed the low level of basic science processes in all textbooks (15.3\%), and the study sample textbooks lacked the integrated science processes.

The study of Al-Shu'aili and Khataybah (2003) investigated all the scientific activities cited in the science textbooks for the first four grades in the basic education stage in Oman. Its aim was the analysis of these activities with the aim of identifying the included science processes. The results of the study revealed the non-existence of measurement scientific activities in the first grade textbook, while the skill of deduction in the textbooks of second, third and fourth grades was not dealt with. The study also revealed the science process with the high percentage for the first grade was observation, communication in the textbooks of second and third grades, and the process of induction had the most occurrences. The study recommended the inclusion of the processes of using time and place relationships and the application of mathematical processes.

Ba'arah (2003) conducted a study with the aim of investigating the basic science processes of the scientific activities of the science textbooks in the basic stage in Jordan through content analysis. The study concluded that 
the induction process had the highest ratio of $39 \%$, while the least ratio was for classification process. The results also indicated the non-inclusion of both processes of using place and time relationships and the application of mathematical processes. The study recommended the necessity for the importance of the inclusion of science processes in science textbooks for all study stages, especially the processes of both using time and place relationships and the application of mathematical processes.

Abu Jahjooh (2008) conducted a study in which he sought to analyze content in order to investigate the availability of the basic and integrated science processes in science textbooks for the first to the teeth grades. The study concluded that the biggest ratio was for the process of observation, while the least ration was for the process of assuming assumptions (hypotheses). The study recommended the enrichment of science textbooks with more pictures of science processes.

Al-Quteish (2012) aimed in his study to investigate the extent of the availability of science processes in the teacher's guide for activities and scientific experiments of the grads from four to eight in Jordan, through their content analysis. The study concluded that the most frequent basic science process in all the guidebooks was observation, whereas the interpretation process, integrated science process, the most frequent. The activities of the study did not include the processes of induction and putting hypotheses. The study recommended the necessity for concern about balance in science processes in science textbooks. The study recommended conducting a study about the inclusion of science processes in the basic stage textbooks in Jordan.

Okeili and Omar (2013) conducted a study with the aim of investigating the science processes included in the activities of science textbooks for the third elementary grade in Saudi Arabia. After conducting the analysis process, the two researchers concluded that the observation process was the most included process in the activities of the study big the study recommended the necessity for the balance in the big inclusion of science processes in school textbooks, by conducting further studies about the topic in science textbooks for other study stages.

\section{Commentary on the Previous Studies}

Through reviewing the preview studies, we notice:

1) The Arab researchers, with their different countries, perceive the importance of the inclusion of science textbooks and their guidebooks with science processes.

2) A group of studies completely analyzed science textbook's such as the study of Al-Aagha and Al-Za'aneea (2000) and Abu Hujooj's (2008), while the other studies were restricted to the analysis of cited scientific activities like (Al-Shu'arah \& Khatatbah, 2003; Anderson, 1992; Ba'arah, 2003; Okeli \& Omar, 2013).

3) Al-Quteishan (2012) was interested in the analysis of the teacher's guidebook as being a basic reference for teaching sciences.

4) The agreement of all the studies that content analysis is the appropriate method for the study topic.

5) The agreement of all the studies about the existence of a weak point in the ratio of the inclusion of science processes in textbooks, activities and teacher's gaide.

6) A group of studies sought to include only the basic science processes (Al-Shu'aili, Khataybah, \& Ba'arah, 2003; Okeili \& Omar, 2013). The other studies included the basic and integrated science processes (Al-Aagha \& Al-Za'ancen, 2000; Abu Jahjooh, 2008; Al-Quteish, 2012).

7) All the previous studies recommended the necessity for the balance in the ratios of science processes and the emphasis of other school textbooks on that.

8) It appears through the result of Ba'ara's study (2003), which investigated the science activities in the basic stage in Jordan that the induction stage had the biggest ratio of $39 \%$, while the least ratio was for classification the study of Kuteish (2012), which dealt with the teacher's guidebook for activities and scientific experiments for the grades from the fourth to the eighth in Jordan, revealed that the most frequent science process in all the guides was observation. This signifies the need for an integrated view when writing science textbooks at all different and advanced grades.

Through the review of the previous points, the present study is consistent with the previous studies in its topic, namely science processes in their research method of content analysis. It also conforms with then in the necessity for searching for the inclusion of science processes in science textbooks and the identification of the response of the anthers of new school textbooks to the recommendations of educational studies and their non-imprisonment on the shelves of libraries. The present study aims at analyzing the science textbooks of the first three grades in 
Jordan, after their development with the aim of avoiding their week points as perceived by the Ministry of Education with all its departments (Ministry of Education, 2013).

It has prepared science textbooks for these grades which combine both sides of scientific knowledge, the theoretical and the practical, in the form of scientific activities, taught in an integrated way therefore, the study dealt with the content of school textbooks with their activities. To the two researcher's knowledge, the study is the first which dealt with science textbooks in Jordan after the modification.

Study problem and Questions:

The basic education stage is a basic and important one in students' learning. The teaching of sciences in this stage is not confined to the student's perception of science components, taking into accountant importance, but it goes beyond that to the training of students for scientific thinking, which is manifested in science processes with all their different types. For achieving the aims of learners' scientific education, and in the light of the ability of the students of basic stage to practice the science processes connected with tangible material actions, there should be a transfer from the science textbook based on gathering information to a textbook which encourages students, through its content, to practice science processes which have been able to build meaningful perceptions.

As a result of the importance of science textbooks in the success of the aspired purposes and aims, this has been of the main interest of researchers and people specialized in order to investigate its level and achievement extent of what it has been set for and its suitability for students (Chiappetta, 2007), through its analysis with the aim of reaching an objective organized description of its content in order to develop curriculum and improve its level (Sallamah, 2009).

The Ministry of Education in Jordan, Showing care about raising the level of teaching outputs and improving its quality, it has made changes for the science textbooks of the first three grades since the beginning of the academic year 2014-2015 and as the basic stage is a crucial one for all educational and societal institutions, the evaluation of school textbooks of this stage is of a great importance. Therefore, the present study came to analyse the science textbooks of the first three grades, with the purpose of investigating their inclusion of science processes as considered as one of the national criteria of scientific education by answering the following study questions:

1) What is the availability extent of basic science processes in science textbooks of the first three grades of the basic education stage in Jordan?

2) What is the availability extent of integrated science processes in science textbooks of the first three grades of the basic education grades of the basic education stage in Jordan?

3) What is the inclusion extent of basic and integrated science processes and their available ratio in science textbooks of all the first three grades of the basic education stage in Jordan?

\section{Significance of the Study}

The study derives its significance from the importance of the basic stage in the educational system which aims at providing society with scientifically educated individuals. The study also comes as a response to the plans of the Ministry of Education to develop the curriculum and textbooks for this specific study stage as it has a great importance in distinguishing the outputs of school education, through the process of content analysis as being a scientific method which aims at inducing facts and presenting them in a clear and logical way.

The study also acquires its significance from the importance of science processes which the theoretical studies emphasize their importance the study sceks to determine the in clusion extent of science processes in the units of the textbooks of the first three grades hewly authorized by Jordanian ministry of Education (2014/2015).

The study is considered the first, to the knowledge of the two researchers, which investigated this aim and these grades. It came as a response to many previous studies which investigated the obstacles against students' understanding of science (Bani Khalef, 2011; Al-Qadiri, 2004; Ba'arah, 2002), which pointed out that the content of school textbooks may be a main reason which hinders students' understanding of science. The results of the study may call researchers to conduct further studies about the evaluation of school textbooks.

\section{Study Limitations:}

-The study is limited to the science textbooks of the first three grades in Jordan.

-The analysis of the above mentioned textbooks relies on the procedural definitions and indicators determined in the present study for science processes. 


\section{Procedural Definitions}

-Science processes are the skills and potentials and necessary mental processes for appropriately applying the patterns of science and scientific thinking (Zaytoon, 1993; Marshall, 1991).

-The two researchers, in this study, depended on the classification of science processes into basic and integrated.

-Basic science processes skills are the processes of observation, measurement, classification, prediction, deduction, using members, using place and time relationships and communication.

-Integrated science processes skills are the processes of data explanation, control of variables, putting hypotheses and experimentation.

-Science textbooks are the school textbooks for the subject of science (with both first and second parts for the first, second and third grades whose instruction is adopted in all public schools in the Hashemite kingdom of Jordan, starting from the academic year 2014/2015 (first edition of each textbook)).

-Analysis unit which is the process of linguistically coding registered data and included messages in an organized and objective way, these may be words, sentences, paragraphs, drawings and shapes (Stemler, 2001). In this study, the content analysis unit is the sentence and it means "The least limit of words which give a meaning, a followed by a comma, question mark or period, as cited it the school textbook. Pictures, shapes and questions were excluded from the end of each unit".

\section{Study Methodology}

The two researchers, in their study, followed the descriptive analytical method, based on the description of the phenomenon as it is through the investigation and analysis of the stated research problems, by using the method of content analysis which is one of the methods of scientific research that aims at quantitative and qualitative description of content, based on specific criteria. The two researchers used it in this study because it the most suitable for achieving the aims of the study.

Population and sample of the study:

The study population consisted of science textbooks of the first, second and third elementary grades, that have been taught starting from 2014/2015, the number of which was six, two parts for each grade, a part for each academic semester. The number of the pages of these textbooks was (323). Table 1 shows the science checkbooks distributed according to grade semester, edition, publication year for each textbook, publisher and number of units.

Table 1. Distribution of general science textbooks according to grade, edition, year of publication, publisher, place of publication, units in each textbook

\begin{tabular}{ccccccc}
\hline $\begin{array}{c}\text { General information about } \\
\text { selected textbooks }\end{array}$ & \multicolumn{2}{c}{ First elem. Grade } & \multicolumn{2}{c}{ Second elem. Grade } & \multicolumn{2}{c}{ Third elem. Grade } \\
\hline Edition No. & The first & The second & The first & The second & The first & The second \\
Publication year & 2014 & 2014 & 2014 & 2014 & 2014 & 2014 \\
Publisher & & & & Ministry of Education & \\
Edition place & & Printing places of the ministry of Education curricula Management \\
Number of units & 4 & 4 & 4 & 4 & 4 & 4 \\
\hline
\end{tabular}


Table 2 shows the titles of units, their arrangement, number of lessons for each textbook.

Table 2. Characteristics of the units of science textbooks which were analyzed for the academic year 2014/2015

\begin{tabular}{|c|c|c|c|c|c|c|c|c|c|}
\hline \multirow[b]{2}{*}{ Textbook } & \multicolumn{3}{|c|}{ First part } & \multicolumn{6}{|c|}{ Second part } \\
\hline & $\begin{array}{c}\text { Unit arrangement } \\
\text { and title }\end{array}$ & $\begin{array}{l}\text { No. of } \\
\text { lessons }\end{array}$ & $\begin{array}{l}\text { No. of } \\
\text { pages }\end{array}$ & $\begin{array}{l}\text { Unit arrangement } \\
\text { and title }\end{array}$ & $\begin{array}{l}\text { No. of } \\
\text { lessons }\end{array}$ & $\begin{array}{l}\text { No. of } \\
\text { pages }\end{array}$ & $\begin{array}{l}\text { No. of } \\
\text { lessons }\end{array}$ & $\begin{array}{c}\text { No. } \\
\text { pages }\end{array}$ & $\begin{array}{c}\text { No. of } \\
\text { analysis units }\end{array}$ \\
\hline \multirow{4}{*}{$\begin{array}{l}\text { Science for first } \\
\text { elementary grade }\end{array}$} & $\begin{array}{l}10 \text { Human body } \\
\text { its health }\end{array}$ & 8 & 17 & 5 water & 5 & 11 & 37 & 80 & 320 \\
\hline & $\begin{array}{l}20 \text { Living creas } \\
\text { tures, solides }\end{array}$ & 3 & 7 & 6 the air & 3 & 7 & & & \\
\hline & 30 Animals & 5 & 10 & 7 plants & 6 & 11 & & & \\
\hline & 40 rocks and soil & 4 & 6 & 8 magneticism & 3 & 7 & & & \\
\hline \multirow{4}{*}{$\begin{array}{l}\text { Science for sec. } \\
\text { elem. Grade }\end{array}$} & 10 animals & 4 & 13 & Plants & 3 & 9 & 36 & 87 & 340 \\
\hline & 20 Measurement & 3 & 13 & $\begin{array}{l}\text { Substunce } \\
\text { characters }\end{array}$ & 5 & 13 & & & \\
\hline & 30 Heat & 6 & 17 & Sound & 6 & 11 & 44 & 107 & 400 \\
\hline & 40 light & 4 & 9 & environments & 5 & 15 & & & \\
\hline \multirow{4}{*}{$\begin{array}{l}\text { Light Science for } \\
\text { third elem. Grad }\end{array}$} & $\begin{array}{l}10 \text { Substance and } \\
\text { transfere }\end{array}$ & 4 & 16 & Water & 4 & 17 & & & \\
\hline & $\begin{array}{l}20 \text { Plats and their } \\
\text { parts }\end{array}$ & 5 & 20 & Earth sciences & 6 & 18 & & & \\
\hline & $\begin{array}{c}30 \text { Powers and } \\
\text { machines }\end{array}$ & 6 & 13 & Animals & 8 & 17 & & & \\
\hline & 40 Life origin & 5 & 14 & $\begin{array}{l}\text { Relationship of } \\
\text { living creatures } \\
\text { with their } \\
\text { environments }\end{array}$ & 3 & 10 & & & \\
\hline
\end{tabular}

\section{Study Instrument (Appendix 1)}

After reviewing the previous studies which dealt with the topics of science processes and the results they reached (Al-Aaha \& Al-Za'aneea, 2000; Ba'arah, 2003; Al-Shu'aili \& Khataybah, 2003; Abu Mahjooj, 2008; Al-Quteish, 2012; Okeili \& Omar, 2013), the two researchers prepared a preliminary list of the basic and integrated science processes and their first indicators, the test validity and reliability were verified.

Instrument validity: five judges specialized in curricula and methods of teaching sciences and Arabic language expressed their opinions about the instrument in order to appear in its final form. The basic science processes were determined as eight; observation, measurement, classification, deduction, predication, acing numberers and the use of place and time relationships and communication and other four integrated processes: data explanation, control of variables, stating hypotheses, and experimentation. Concerning context analysis, which aims at determining the basic and integrated science processes in the textbooks representing the sample of the study, sentences were selected as the unit of analysis because they were short, in the selected grades, expressing on idea, where the paragraphs, include science processes. This was followed by the classification of each paragraph into the appropriate science process through the indicators of each process, frequencies for each process were calculated and its ratio. Instrument reliability: to verify the analysis reliability, the two researchers analyzed a 
sample of the textbooks under study, contemporary with another researcher, consistency ratios between percentages were calculated in each analysis according to following formula:

The number of analysis units agreed upon the number of whole analysis units in the analysis sample.

Keya coefficients for consistency were calculated (They are the consistency rabos after removing chance coeffient).

Kaya coefficient $=$ consistency ratio-chance consistency ratio.

After conducting calculations, it was found out that the consistency ratio between the two analyses was (88) and kaya coefficicat for them was (0.86); it is considered as an acceptable limit and also strong according to the standard score in the authorized estimate ladder of kaya coefficient (Table 3).

Table 3. Anthorized estimate ladder of kaya coefficient

\begin{tabular}{cc}
\hline Statistical kaya coefficient & Power degree \\
\hline Weak & $<0.00$ \\
Superficial & $0.20-0.00$ \\
Appropriate & $0.20-0.41$ \\
Medium & $0.60-0.041$ \\
Strong & $0.80-0.61$ \\
Distinguished & $1.00-0.81$ \\
\hline
\end{tabular}

-Statistical processing: the research aimed at identifying the basic and integrated science processes in the science textbooks of the first three grades in Jordan. For answering the study questions, frequencies and ratios were used.

-Study results and their discussion:

First: the results relating to the answer of the first question which states: what is the availability extent of the basic science processes in the science textbooks of the first three grades of the basic education stage in Jordan? To answer the question, the tow researchers analyzed all the science textbooks of the study by using the study instrument as already explained. The frequencies and ratios were calculated as explained in Table 4.

Table 4. Frequencies and ratios of the basic science processes in the science textbooks of the first three grades

\begin{tabular}{|c|c|c|c|c|c|c|c|c|c|c|c|}
\hline $\begin{array}{l}\text { Science } \\
\text { textbook } \\
\text { for }\end{array}$ & $\begin{array}{c}\text { Basic science } \\
\text { processes }\end{array}$ & Frequ. & Ratio \% & $\begin{array}{l}\text { Science } \\
\text { textbook } \\
\text { for }\end{array}$ & $\begin{array}{c}\text { Basic sc. } \\
\text { Proce. }\end{array}$ & Frequ. & Ratio \% & $\begin{array}{c}\text { Science } \\
\text { textbook } \\
\text { for }\end{array}$ & $\begin{array}{c}\text { Basic sc. } \\
\text { Proce. }\end{array}$ & Frequ. & Ratio \% \\
\hline \multirow{10}{*}{$\begin{array}{l}\text { First } \\
\text { elem }\end{array}$} & Observe. & 147 & 46 & \multirow{10}{*}{$\begin{array}{l}\text { Sec. } \\
\text { elem }\end{array}$} & Observe. & 156 & 46 & \multirow{10}{*}{$\begin{array}{l}\text { Third } \\
\text { elem }\end{array}$} & Observe. & 192 & 48 \\
\hline & Measure. & 5 & 2 & & Measure. & 42 & 13 & & Measure. & 24 & 6 \\
\hline & Classif & 47 & 15 & & Classif & 9 & 3 & & Classif & 6 & 2 \\
\hline & Deduction & 12 & 4 & & Deduction & 5 & 2 & & Deduction & 32 & 8 \\
\hline & Predict & 18 & 6 & & Predict & 6 & 1 & & Predict & 20 & 5 \\
\hline & $\begin{array}{l}\text { Use of } \\
\text { numbers }\end{array}$ & - & - & & $\begin{array}{c}\text { Use of } \\
\text { numbers }\end{array}$ & 12 & 48 & & $\begin{array}{c}\text { Use of } \\
\text { numbers }\end{array}$ & 1 & 5 \\
\hline & $\begin{array}{l}\text { Place and time } \\
\text { relations }\end{array}$ & - & - & & $\begin{array}{l}\text { Place and time } \\
\text { relations }\end{array}$ & - & - & & $\begin{array}{l}\text { Place and time } \\
\text { relations }\end{array}$ & - & - \\
\hline & \multirow[t]{3}{*}{ communication } & - & - & & communication & - & - & & communication & - & - \\
\hline & & & & & & & & & $\begin{array}{l}\text { Use of place } \\
\text { and time rela. }\end{array}$ & - & - \\
\hline & & & & & & & & & Com & - & - \\
\hline
\end{tabular}


It is noticed from the data of Table 4 that:

-Most basic science processes are included in the science textbooks for each grade of the study is the observation process with a ratio of $(46 \%, 46 \%$, and $48 \%)$ successively.

-The tow science textbooks of the first elementary grade included five basic science processes distributed as follows: observation, classification, prediction and then measurement $(46 \%, 15 \%, 6 \%, 4 \%$, and $2 \%)$, while three processes were not included: use of numbers, use of time and place relationships and communication.

-The two science textbooks of the second elementary grade included six basic science processes distributed in arrangement to the following: observation, measurement, use of numbers, classification, deduction and then prediction $(46 \%, 13 \%, 12 \%, 2 \%, 1 \%)$, but they did not include both processes of the use of time and place relationships and communication.

-The two science textbooks of the third elementary grade included six basic science processes distributed to the following order: observation, dedication, measurement, prediction, classification, and then use of numbers $(48 \%, 8 \%, 6 \%, 5 \%, 2 \%, 1 \%)$, but they did not include the processes of time and place relationships and communication.

Through the review of the previous observations, it is noticed that the most included basic science processes in the science textbooks of the first, second and third grades is the observation process with ratios of $(46 \%, 46 \%$, $48 \%)$.

This result is the tangible fact that the authors of the textbooks of the first three grades greatly concentrate on the process of observation, considering the series as the first gate for knowledge in these grades, and students training of the observation of phenomena and events is one of the aims of teaching sciences in the basic education stage, and it is the cornerstore for other basic and integrated science processes (Eubel, 1993). It is the point from which students' interaction starts from the conteat of lessons. Observation came directed by a main question in the textbooks of the first three grades of the study. In spite of the fact that this result encourages optimism, the previous studies show the existence of balance and organization in the concern about the basic science processes with different textbook and grades. The ratio of the inclusion of measure process in the two textbooks of the first grade was $(2 \%)$ and was $(6 \%)$ for the two textbooks of the third grade, but it was $(13 \%)$ for the two textbooks of the second grade, although the learning of this process is very important, even if its identified shape which is based on the comparison of things or the use of infrecise instruments such as the inch or the foot. It is a necessary process for the other science processes and specifically the tow processes of classification and growth (Wolfinger, 2000). The two researchers think that the content of the textbooks of the first and third grades led to this result (human body, and its health, living creatures and solids, animals, water, the air, earth sciences), while one unit was specified for three lessons for measurement, one unit with six lessons for heat in the see and grade textbooks, as being topics in which the process of measurement is employed in a great way.

This result asks for the variety of the topics of the content of the first and third grades. The ratio of the inclusion of the process of number use was $(12 \%)$ in the two textbooks of the second grade and was (1\%) for the two books of the third grade, while it was not included for the textbook of the first elementary grade. This result could be justified by the authors of textbooks that the first grade students will learn numbers and arithmetic processes when attending school, but this could be justified in the first part of the first grade, not in the second part, or in the two textbooks of the third grad, taking into account that they can perform arithmetic processes with their variety. This result could be attributed to the fact the anits of the science textbooks for the first and third grades emphasized the concepts of biology in particular as they can perform arithmetic processes with their variety.

Concerning the decrease in the inclusion ratio of the deduction process in the textbooks of the first and second grades which was $(4 \%)$ and $(2 \%)$ successively, this fact requires identification, as students ability to perform deductions based on what they have observed and connected with previous information, is considered as a sign of the student's success in reaching a meaningful understanding that cannot be achieved without increasing the inclusion ratio of deduction process in the content of these textbooks through asking questions for stimulating students to connect the information they have learnt with new information (Zeitoon, 2001).

Concerning the non-inclusion of the two processes of the use of place and time relationship and communication, is a very dangerous thing because the students capable of performing all science processes are those who are more aware than others of the content of their school textbooks (ESAU, 2008). This cannot be achieved with the inclusion of science processes than. 
Others, the fact that communication process reflects the student's ability to express scientific ideas to others, although it is verbal in the case of the first grade students. Students should also acquire the ability to discuss their ideas and what they have reached with their teachers and colleagues if we want to prepare small explorers (Martin, 2006).

This result is consistent with Al-Quteish (2012) and Abu Jahjooj (2008), but it is inconsistent with Al-Shuaili and Khataybah (2003) and Ba'arah (2003).

Second: the results relating to the answer of the second question of the study which states: what is the availability extent of the integrated science processes in the science textbooks of the first three grades in the basic education stage?

To answer the question, the two researchers analyzed the units of all the science textbooks of the study by using the instrument of the study as already explained; the frequencies and ratios were calculated as explained in the data of Table 5 .

Table 5. Frequencies and ratios of the integrated science processes in the anits of science textbooks of the first three grades

\begin{tabular}{|c|c|c|c|c|c|c|c|c|c|c|c|}
\hline $\begin{array}{l}\text { Science textbook } \\
\text { for grad }\end{array}$ & $\begin{array}{l}\text { Integrated science } \\
\text { processes }\end{array}$ & Freq. & Ratio\% & $\begin{array}{l}\text { Sc. Text. } \\
\text { Grade }\end{array}$ & $\begin{array}{l}\text { Intig. Sc. } \\
\text { Proc. }\end{array}$ & Freq. & Ratio \% & $\begin{array}{c}\text { Sc. Tex. } \\
\text { Grade }\end{array}$ & $\begin{array}{l}\text { Integ. Sc. } \\
\text { proc }\end{array}$ & & \\
\hline & $\begin{array}{c}\text { Assum. } \\
\text { Hypotheses }\end{array}$ & 7 & 2 & & $\begin{array}{c}\text { Assum. } \\
\text { Hypotheses }\end{array}$ & 17 & 5 & & $\begin{array}{c}\text { Assum. } \\
\text { Hypotheses }\end{array}$ & 2 & 8 \\
\hline & Explana & 35 & 11 & & Explana & 39 & 12 & & Explana & 6 & 23 \\
\hline & Variables control & 5 & 2 & & $\begin{array}{c}\text { Variables } \\
\text { control }\end{array}$ & 17 & 5 & & $\begin{array}{c}\text { Variables } \\
\text { control }\end{array}$ & 5 & 20 \\
\hline & Experi-mentation & 27 & 7 & & $\begin{array}{l}\text { Experi- } \\
\text { mentation }\end{array}$ & 44 & 13 & & $\begin{array}{l}\text { Experi- } \\
\text { mentation }\end{array}$ & 14 & 44 \\
\hline
\end{tabular}

It is noticed from Table 5 data that it includes all the integrated science processes in the textbooks of the first three grades. The most included integrated science process in the textbooks of the study was the process of experimentation with a ratio of $(13 \%, 12 \%, 7 \%)$ respectively. It appears that:

-The two science textbooks of the first basic grade included all integrated science processes, distributed as follows: explanation, experimentation, stating hypotheses and variables control $(7 \%, 11 \%, 2 \%, 2 \%)$.

-The two science textbooks of the second basic grade included all the integrated science processes, distributed as follows: experimentation, explanation, stating hypotheses and variables control $(13 \%, 12 \%$, $5 \%, 5 \%)$.

-The two science textbooks of the third basic grade included all the integrated science processes, distributed as follows: experimentation, explanation, variables control and stating hypotheses $(14 \%, 6 \%, 5 \%, 2 \%)$.

It is noticed from the data of Table 5 that the process of experimentation is the most included integrated science process in all the textbooks of the three grades with the ratios of $(7 \%, 13 \%, 14 \%)$ of the first, second and third grades respectively. This result is consistent with the concentration of the content of textbooks on scientific activities, where two activities at least were allotted for each less on, as the student is asked to perform different experiments according to organized steps. It also appears from the data of Table 5 that there is a variety in the interest in the other integrated processes, and especially the process of stating hypotheses in the textbooks of the first and third grades with a ratio of $2 \%$. The explanation of the result could be that it came consistent with the way in which the scientific experiments in the textbook was presented, as they came in the form of successive steps which did not give students the opportunity to form different answer, in spite of the fact that the inclusion ratios of the explanation process were $(11 \%, 12 \%, 6 \%)$ for the three grades respectively. Students were asked to explain the data they obtained, or the analysis of the reasons of a certain phenomenon or event, and the link between the cause and the result, the fact which points out the need for balance and organization in the inclusion of integrated science processes in all the textbooks of the study. 
Third: the results relating to the answer of the third answer of the study which states: what is the inclusion extent of the basic and integrated science processes and their available ratios in all the science textbooks of the first three grades of the basic education stage?

To answer this question, the two researchers analyzed the units of all the science textbooks by using the study instrument as already explained; frequencies and ratios for each of the basic and integrated science processes, stated in all science textbooks, were calculated, as explained in the data of Tables 6 and 7.

Table 6. Frequencies of basic and integrated science processes in science textbooks of the first three grades

\begin{tabular}{|c|c|c|c|c|c|}
\hline \multicolumn{4}{|c|}{ Frequency } & \multirow{2}{*}{ Total } & \multirow{2}{*}{ Percentage } \\
\hline Basic science processes & First elem. Grade & Sec. elem, grade & Third. Elem, grade & & \\
\hline Observation & 147 & 156 & 192 & 495 & 63 \\
\hline Measurement & 5 & 42 & 24 & 71 & 9 \\
\hline Classification & 47 & 9 & 6 & 62 & 8 \\
\hline Deduction & 12 & 5 & 32 & 49 & 6 \\
\hline Prediction & 18 & 6 & 20 & 44 & 6 \\
\hline Use of numbers & - & 48 & 5 & 53 & 7 \\
\hline $\begin{array}{l}\text { Use of place and time } \\
\text { relationship }\end{array}$ & - & - & - & - & - \\
\hline \multirow[t]{2}{*}{ Communication } & - & - & - & - & - \\
\hline & & & & 774 & \\
\hline
\end{tabular}

Table 7. Rations of basic and integrated science processes in science textbooks of the first three grades

\begin{tabular}{cccccc}
\hline Integrated science processes & First elem grade & Sec. elem grade & Third elem grade & Total & Percentage \\
\hline Stating hypotheses & 7 & 17 & 8 & 32 & 11 \\
Explanation & 35 & 33 & 23 & 97 & 34 \\
Variables control & 5 & 17 & 20 & 42 & 14 \\
Experimentation & 27 & 44 & 44 & 115 & 40 \\
& & & & 286 & \\
\hline
\end{tabular}

Figures 1 and 2 show the ratios (percentages) of basic and integrated science processes stated in all the science textbooks of the first three grades. It is noticed that the most frequented basic science processes is the process of observation with a ratio of $(63 \%)$, while the least frequenced processes are deduction and use of numbers with a ration of $7 \%$ for each, whereas the processes of place and time relationships and communication in all textbook are not included. This result emphasizes the necessity for balance and organization in the inclusion of all basic science processes. 


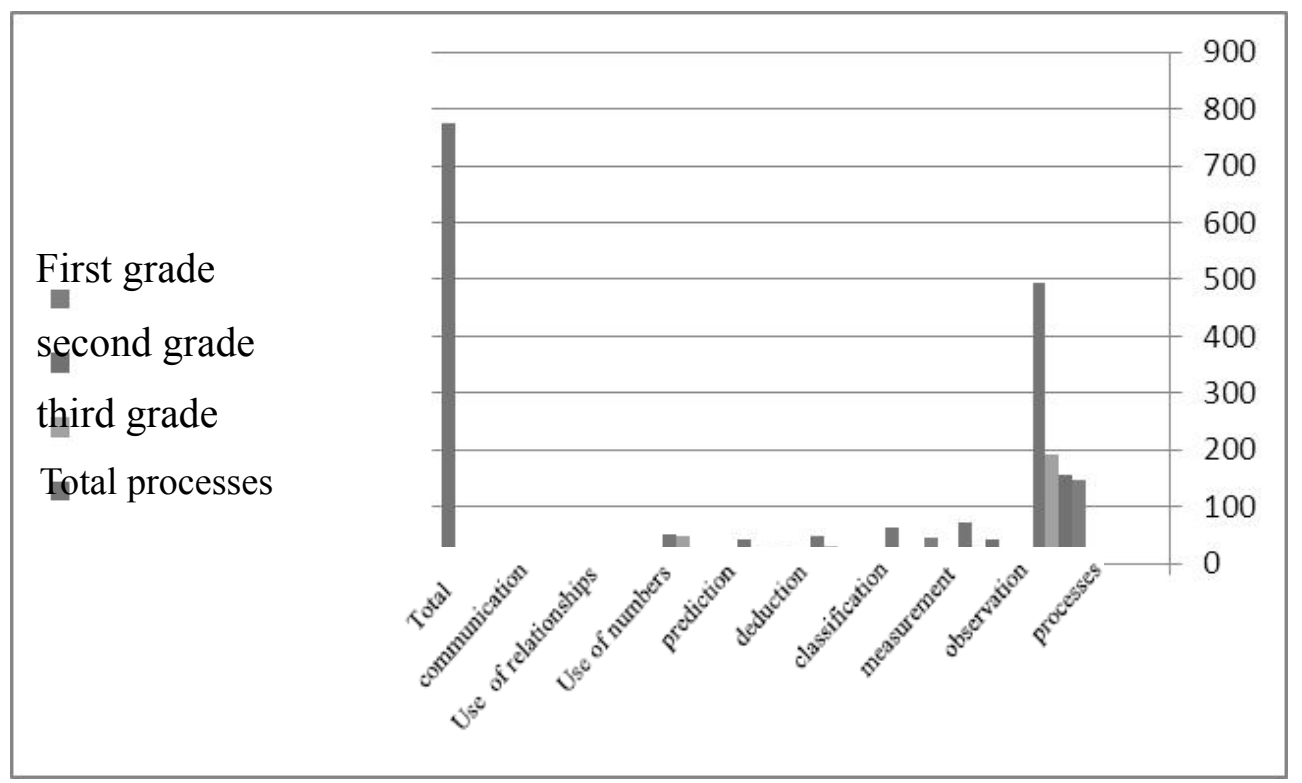

Figure 1. Percentages of basic science processes stated in all the science textbooks of the first three grades

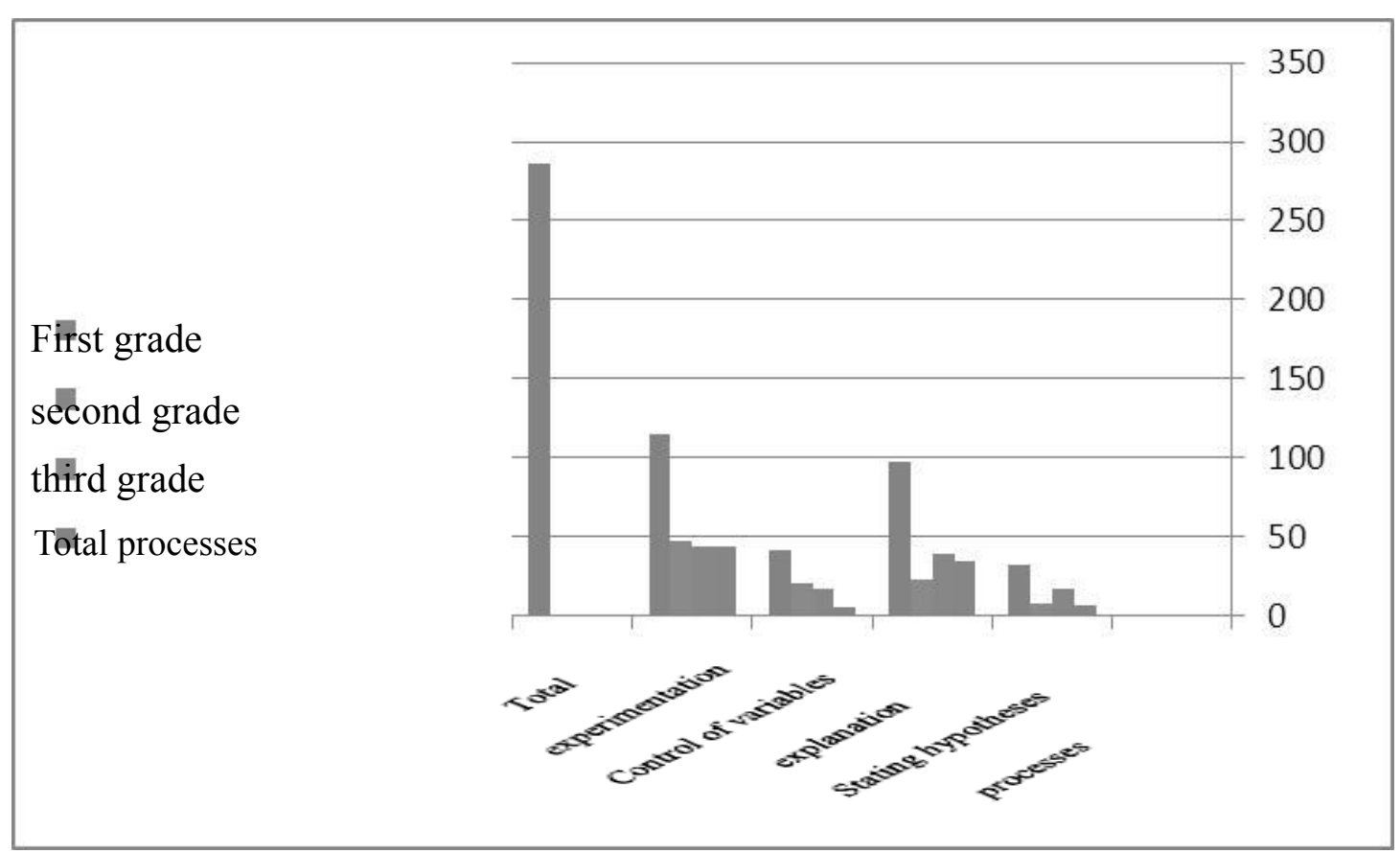

Figure 2. Percentages of integrated Science Processes stated in all the Science textbooks of the first three grades

Figures 1 and 2 show that the most frequented basic science processes in the process of observation with a percentage of $63 \%$, while the least frequented are the processes of deduction and use of numbers with a percentage of $6 \%$ for each, while the two processes of using place and time relationships and communication in all textbooks were not included.

This result emphasizes the necessity for balance and organization in the inclusion of all basic science processes.

Also, the most frequently in to grated science processes in all science textbooks is experimentation with a percentage of $40 \%$, while the least frequently process is stating hypotheses with a percentage of $11 \%$. Figures 1 and 2 show the non-inclusion of two basic processes of the basic science processes, namely, the use of place relationships and communication, against the inclusion of all integrated science processes. It is noticed that the experimentation process came with a percentage of $40 \%$ preceding the ration of the inclusion of basic and 
integrated science processes, except for the process of observation. This seems to be due to the authors' desire that students should interact in an organized way with the consent of the textbook by concentrating on observation and their desire that the student should conduct scientific experiments, but the other basic science processes should be emphasized, if observation to be complete and useful, and for experimentation to be meaningful, it should be through the student's building of concepts and knowledge on solid grounds based on his/her thinking and performance of activities connected with the basic science processes, first and then experimenting them based on his/her implementation of already determined step, by the help of science textbooks which urge students to reach open-ended answers for activities, and not just by looking for answers at the end of each experiment. From the researchers views, this happens by changing the way of presenting scientific activities in science textbooks, in a way that stimulates the student to really try and experiment by practicing integrated and basic science processes all this cannot be achieved without the inclusion of integrated and basic science processes in an organized and balanced way in both textbooks of the one grade, and the between textbooks of the first three grades, by preparing them in an integrated way in topics and concepts.

\section{Recommendations}

In light of the results achieved, the two researchers recommend the following:

-The inclusion of basic science processes in the textbooks of the first three grades in an organized balanced way.

-The inclusion of the process of using numbers in the science textbook of the first elementary grade and the taso processes of using time and place relationships and communication process in the science textbook of the first three grades.

-Emphasizing the necessity for the students performance of open ended scientific experiments, as being the perfect way which urges them to use and practice science processes.

-Suggesting the conducting of a study about students' ability to perform science processes in the first three grades in Jordan.

-Suggesting the conducting of a study about the science teachers' assessment of the changes that happened to the science curricula of the first three grades in Jordan.

\section{References}

Abdulhadi, J. A. D. (2003). The Evaluation of Drills Notebook and the Activities of science curricula in the Elementary stage in Light of Visual communication Methods and the Basic science processes. Magazine of scientific Education, 6(2), 1-27.

Abu Aathrah, S. (2012). Development of scientific concepts and the skills of science processes. Amman, Dar Al-Thakafah.

Abu Jahjooh, Y. (2008). The Availability Extent of science processes in the science Textbooks of the Basic Education stage in palestine. Al-Najah University megalive for Researches, 22(5).

Al-Aagha, I., \& Al-Za'aneen, J. (2000). The Availability Extent of Some Components of Scientific Enlightenment in the science Textbooks of Elementary stage. The Fourth scientific Conference of the Egyptian Society for scientific Education.

Al-Qndiri, S. (2004). Obstacles of students Learning of the concepts of physics as perceived by the Teachers of physics in the north of Jordan. Al-Manarah, Aal Al-Beit university, 10(4), 217-254.

Al-quteish, H. (2012). The science processes included in the Teacher's Guidebook of scientific Proclivities and Experiments of the science textbooks of the Basic stage in Jordan. Open Jeruse university magazine for researches and studies, 27, 52-82.

Al-seifi, S. (2011). Measuring the science Processes of the Public Education students in the sultanate of Oman an unpublished Master thesis. Al-sulat Qabooss University.

Al-Shu'aili, A., \& Khataybah, A. (2003). The Basic Science processes Included in the scientific Activities of the science Text Books of the first four Grades of the Basic Education stage in the sultanate of Oman. Magazine of Educational and psychological sciences, 4(1).

Al-Suweidi, B. (2010). The Mastery Level, of the Nine Grade students of the Basic Education, of the Basic science processes of science subject. Damascus University magazine, 26. 
American Association for the Advancement of Science [AAAS]. (1993). Benchmarks for Scientific Literacy. New York: Oxford University Press.

Anderson, T. (1992). A Text Analysis of Two Pre-Secondary School Science Activtie. Urbana, Chapaign, Ill: University of IUinoise at Urbana, Champaign Centre for the Study of Reading.

Aziz, M. S., \& Zain, A. N. M. (2010). The Inclusion of Science Process Skills in Yemeni Secondary School Physics Textbooks. European Journal of Physics Education, 1, 44-55.

Badawi, R. (2003). Development of Mathematical concepts and skills of pre-school children. Ammar, Dar Al-Fikr for Publication and Distribution.

Bani Khalaf, M. (2011). Weakness As Pects in the science Learning of the Basic Tenth Grade students as Determined and Estimated by science Teachers in one Educational Area in Jordan. Jordanian Magazine in Educational Sciences, 4(7), 357-369.

Bennett, J. (2003). Teaching and Learning Science. London: British Library.

Carin, A. A., \& Bass, J. E. (2001). Teaching Science as inquiry. Upper saddle River, NJ, Merrill/prentice-Hall.

Chin, C., Brown, D., \& Bruce, B. (2002). Student-Generated Question: A Meaningful Aspect of Learning in Science. International Journal of Science Education, 24(5), 521-549. https://doi.org/10.1080/09500690110095249

Chipappetta, E. L., \& Fillman, D. A. (2007). Analysis of five High School Biology textbooks Used in the United States for Inclusion. Nature of Science International Journal of Science Education, 29(5), 1847-1868.

Department for Education, UK. (2009). The National Strategies. Published on Dcst.gov.uk/National Stratiges, Common Weaknesses in GCSE Science.

Gega, P. (1994). How to Teach Elementary School Science (2nd ed.). New York: MacMillan Publishing Company.

Khataybih, A. (2011). Teaching Sciences for All (3rd ed.). Amman, Dar Al-Masseerah for publication and Distribution.

Mar'I, T., \& Al-Heelah, M. (2004). Modern educational curricula, their concepts, elements, Basics and processes (4th ed.). Amman, Dar Al-masserah for publication and distribution.

Marshall, J. E. (1990). An Investigation of the Construct Validity of the Test of Basic Science Process Skills in Science: A Multitrait-Multimethod Analysis.

Martin, R., Sexton, C., \& Gerlouich, J. (2001). Teaching Science for all Children (3rd ed.). Massachusetts, USA: Allyn and Bacon.

Ministry of Education. (2014). The curriculum of science and its guidelines in the Basic Education stage. General Directorate of curricula and Education Techniques, Amman, Jordan.

Morrow, L. (1994). Current Strategies for literacy Development in Early Childhood Science Texts. Washington DC.: Office of Educational Research and Improvement.

Salamah, A. A. (2009). Methods Teaching science: A Current Applied Handling. Amman, Dar Al-Thakafah.

Simsek, P., \& Kabapinar, F. (2010). The Effect of Inquiry-Based Learning on Elementary Students Conceptual Understanding of Matter, Scientific Process Skills and Science Attitudes. Procedia Social and Behavioral Sciences, 2, 1190-1194. https://doi.org/10.1016/j.sbspro.2010.03.170

Tobin, K., \& Capie, W. (1982). Relationships between Formal Reasoning Ability, Locus of Control, Academic Engagement and Integrated Process Skills Achievement. Journal of Research in Science Teaching, 19(2), 113-121. https://doi.org/10.1002/tea.3660190203

Wolfinger, D. M. (2000). Science in the elementary and Middle School. New York: Longman.

Zeitoon, A. (2010). Current scientific Attitudes in science curricula and their Teaching. Amman, Dar Al-Shorouk.

Zeitoon, K. (2009). The Practices of science and scientific Education. Cairo, the world of Books. 


\section{Appendix}

Appendix 1. The instrument of analyzing the science textbooks of the first three grades of the basic education stage in Jordan in light of science processes

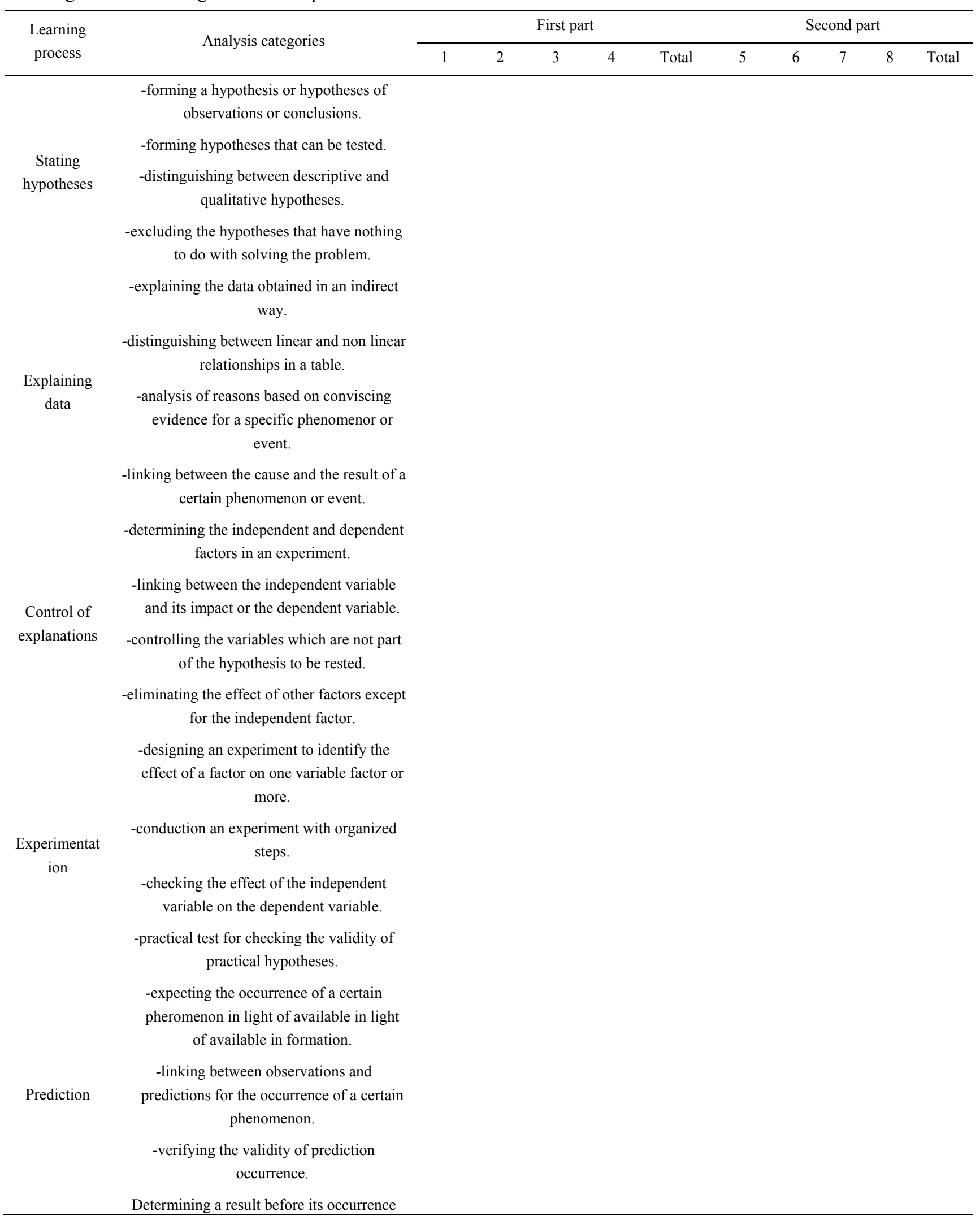


depending on present information.

-quantitative expression about the

characteristics of the phenomenon being

$$
\text { studied. }
$$

-conducting arithmetic processes in order to

Use of

$$
\text { process data. }
$$

numbers

-using mathematical symbols and numerical relationships between scientific concepts.

-determining the measurement units

expressing the phenomenon or event in a precise way.

-describing things or events or phenomena in a scientific preciseness.

-interpreting the available information in a

Communicat verbal or written way.

ion

-presenting results in tables or diagrams.

-preparing the reports about observations or different scientific activities.

\section{Copyrights}

Copyright for this article is retained by the author(s), with first publication rights granted to the journal.

This is an open-access article distributed under the terms and conditions of the Creative Commons Attribution license (http://creativecommons.org/licenses/by/4.0/). 